\title{
Quilombos, política federal de patrimônio e reparação
}

Quilombos, federal heritage policy and reparations

https://doi.org/10.1590/1982-02672020v28d2e57

\section{JOSEANE PAIVA MACEDO BRANDÃO'}

https://orcid.org/0000-0003-3747-4667

Instituto do Patrimônio Histórico e Artístico Nacional / Rio de Janeiro, RJ, Brasil

RESUMO: Considerando pedidos de reparação como solicitações de reconhecimento, é possível pensar em políticas governamentais de patrimônio como esferas que articulam reconhecimento cultural e jurídico-político e mobilizam dinâmicas que ligam Estado, sociedade civil e comunidades detentoras de patrimônio. A constituição de um patrimônio afro-brasileiro nos anos 1980, por meio do tombamento da Serra da Barriga - considerada o local do Quilombo dos Palmares, no século XVII -, teve importante papel de incorporar a dimensão cultural e jurídico-política do reconhecimento, influenciando na dimensão de reparação que a categoria "quilombo" ganhou na Constituição Federal de 1988. Posteriormente, a partir do ordenamento jurídico constitucional, com a criação da categoria "comunidade remanescente de quilombo" e a ampliação dos instrumentos utilizados para identificação e reconhecimento de patrimônios culturais pelo Estado, as políticas e narrativas patrimoniais puderam reconhecer mais do que o desrespeito histórico da escravidão e a posição subalterna dos afrodescendentes na sociedade brasileira. Estas também permitiram o reconhecimento de formas de organização social e cultural específicas que, nesse caso, geram a designação particular "quilombola".

PALAVRAS-CHAVE: Quilombo. Políticas de patrimônio. Reconhecimento social. Reparação.

\begin{abstract}
1. Bacharel e mestre em Ciências Sociais pela Universidade do Estado do Rio de Janeiro (Uerj) e doutora em Sociologia pela Universidade Federal de Sergipe (UFS), tendo realizado doutorado-sanduíche no Centro de Estudos Sociais da Universidade de Coimbra (Portugal). Atualmente é docente do Mestrado Profissional em Preservação do Patrimônio Cultural do Instituto do Patrimônio Histórico e Artístico Nacional (Iphan), no Centro Lucio Costa (RJ). E-mail: <joseane.brandao@ iphan.gov.br>.
\end{abstract}


ABSTRACT: By considering requests for reparations as requests for recognition, one can think of government heritage policies as spheres that articulate cultural and legal-political recognition and that mobilize dynamics that link the State, civil society and heritage-holding communities. The constitution of an Afro-Brazilian heritage in the 1980s, initially through the safeguarding of Serra da Barriga as a heritage site - considered the site of Quilombo dos Palmares in the 17th century - was crucial for the incorporation of the quilombo category into Brazil's 1988 Federal Constitution, assigning reparations with cultural and legal-political recognition. Subsequently, from the creation of the category "quilombo remnant community" at constitutional level and the expansion of the instruments used by the State to identify and recognize cultural heritage, heritage policies and narratives were able to recognize the historical disrespect for slavery and the subordinate position of people of African descent in Brazilian society. Furthermore, the recognition of specific forms of social and cultural organization also became possible, in this case, those that generate the particular designation "quilombola".

KEYWORDS: Quilombo. Heritage policies. Social recognition. Reparation. 


\section{RECONHECIMENTO SOCIAL, REPARAÇÃO E ESCRAVIDÃO}

Partindo da argumentação de Saillant, que trabalha com a perspectiva de que pedidos de reparação são solicitações de reconhecimento, inicialmente serão tratados neste artigo aspectos da teoria social de autores como Axel Honneth e Nancy Fraser ${ }^{2}$ sobre noções de reconhecimento, no que tange às discussões que serão desenvolvidas posteriormente acerca da articulação entre políticas de patrimônio cultural e demandas por reparação de comunidades negras. Saillant ressalta que a contribuição desses e de outros autores que trataram do reconhecimento social foi a criação de conceitos importantes, como "sujeito, o vínculo social, a identidade, o direito e o sofrimento social". ${ }^{3}$

No texto "Da redistribuição ao reconhecimento? Dilemas da justiça da era póssocialista", Nancy Fraser aponta que o fim do "socialismo real", a incapacidade dos Estados de continuar a garantir o crescimento dos mercados no pós-guerra, o acelerado processo de globalização, com o desenvolvimento das novas tecnologias de informação e comunicação, o aumento nos fluxos de mercadorias, informações e pessoas, e a flexibilização das fronteiras nacionais teriam levado à politização das diferenças étnicas e culturais e à despolitização da economia nos movimentos sociais. ${ }^{4}$

Contudo, a autora afirma que a questão da justiça, hoje, exige tanto "lutas por reconhecimento" como "lutas por redistribuição". Para ela, as sociedades contemporâneas teriam dois tipos de mecanismos sociais distintos, um econômico e outro cultural, que produziriam tipos diversos de injustiças e, desse modo, devem ser tratados de forma dualista, mas interconectada. ${ }^{5}$

Por sua vez, Axel Honneth parte do conceito de reconhecimento de Hegel, utilizando-o como fio condutor para compreender o que são os conflitos sociais, sendo a luta por reconhecimento o motor deles. Apropriando-se da psicologia social de George Mead, Honneth afirma que na modernidade os sujeitos se formam por meio de processos de interação social, com expectativas morais de comportamento em três diferentes esferas de reconhecimento, a do amor, a do respeito e a da estima, que, quando não atendidas, podem gerar um sentimento de desrespeito e de injustiça. ${ }^{6}$

Nesse sentido, o aporte teórico de Honneth articula a noção de identidade e é importante para a análise da politização das diferenças étnicas e culturais realizada pelos chamados "novos movimentos sociais".

[...] os motivos de resistência social e da rebelião se formam no quadro de experiências morais que procedem da infração de expectativas de reconhecimento profundamente arraigadas. Tais
2. Fraser (2006); Honneth (2003).

3. Saillant (2016, p. 18).

4. Fraser, op. cit.

5. Ibid.

6. Honneth (2003) apud Bressiani (2011). 
7. Honneth, op. cit., p. 258.

8. Saillant, op. cit.

9. Fraser, op. cit., p. 232.

10. "O mal inscrito em um sistema histórico tem a particularidade de se perpetuar por um longo período de tempo e de ser sentido como tal ao longo de várias gerações ou até mesmo séculos" (Saillant, op. cit., p. 23).

11. Guimarães (2001, p. 160-161).

12. Saillant, op. cit. expectativas estão ligadas na psique às condições da formação da identidade pessoal, de modo que elas retêm os padrões sociais de reconhecimento sob os quais um sujeito pode se saber respeitado em seu entorno sociocultural como um ser ao mesmo tempo autônomo e individualizado; se essas expectativas normativas são desapontadas pela sociedade, isso desencadeia exatamente o tipo de experiência moral que se expressa no sentimento de desrespeito.?

Segundo Saillant, ${ }^{8}$ a teoria de Honneth permite reunir a experiência individual, a coletiva, o direito e o Estado, por conta das três esferas de reconhecimento com que o autor trabalha, que envolvem os níveis individual, intrafamiliar, intracomunitário e jurídico-político. Nesse caso, a experiência de uma identidade positiva implica a relação entre as três esferas do reconhecimento.

Já Nancy Fraser diferencia o que chama de "injustiça econômica" da "injustiça cultural". Nesse sentido, ela considera que o remédio para a injustiça econômica são os processos de redistribuição e, para a injustiça cultural, o reconhecimento. Ambas as injustiças levam a impedimentos da "paridade de participação"; sendo assim, o elemento de participação social também é considerado importante para a experiência de justiça e para uma identidade positiva.

\footnotetext{
Insistirei em distinguir analiticamente injustiça econômica e injustiça cultural, em que pese seu mútuo entrelaçamento. $\bigcirc$ remédio para a injustiça econômica é alguma espécie de reestruturação político-econômica. [...] Embora esses vários remédios difiram significativamente entre si, doravante vou me referir a todo esse grupo pelo termo genérico "redistribuição". O remédio para a injustiça cultural, em contraste, é alguma espécie de mudança cultural ou simbólica. [...] Embora esses remédios difiram significativamente entre si, doravante vou me referir a todo esse grupo pelo termo genérico "reconhecimento". 9
}

Desse modo, reconhecer identidades em um ambiente plural é fundamental nas sociedades contemporâneas e, além disso, é preciso que se assumam também as feridas, os sofrimentos e as injustiças históricas ${ }^{10}$ dos quais grupos minoritários e minorizados foram vítimas em dado contexto. Nesse sentido, há um vínculo entre o reconhecimento de identidades de grupos minoritários ou que passaram por experiências de minorização, a produção de conhecimento acerca do passado de injustiça histórica, os pedidos de reparação de grupos organizados e a resposta da sociedade aos pedidos de reparação em forma de leis, políticas, ações da sociedade civil etc." Saillant, entretanto, argumenta que o reconhecimento não pode se desvincular do discurso da injustiça. ${ }^{12}$ Portanto, reconhecer identidades afrodescendentes na sociedade brasileira implica tratar do passado de colonização e escravidão e de suas consequências. 
Para desnaturalizar a forma como, ainda hoje, a instituição da escravidão é pensada no Brasil, é urgente exercitar o dever de memória em relação aos que não sobreviveram. É preciso também, para além do reconhecimento da dívida do Brasil com todos aqueles que sofrem com o racismo, reconhecer a especificidade da dívida da sociedade brasileira com os descendentes diretos da última geração de africanos. Trazidos à força ao país há menos de 150 anos, seus descendentes compõem a maior parte das comunidades remanescentes de quilombo e dos grupos detentores do patrimônio cultural brasileiro de matriz africana oficialmente reconhecido. ${ }^{13}$

Guimarães, em texto que analisa antropologicamente a expressão "democracia racial" e sua disseminação, mostra como ela foi usada "por ativistas negros, políticos e intelectuais para designar um ideal de convivência inter-racial e um compromisso político de inclusão do negro na modernidade brasileira do pós-guerra". ${ }^{14}$ Segundo o autor, a ideia de que o Brasil era um país sem barreiras legais à ascensão social de pessoas de cor era bastante difundida nos Estados Unidos e na Europa já no século XIX. Gilberto Freyre reafirma a utopia de paraíso racial no Brasil ao contrastar a rigidez da organização patriarcal do país com a flexibilidade das relações raciais.

Até o que havia de mais renitentemente aristocrático na organização patriarcal de família, de economia e de cultura foi atingido pelo que sempre houve de contagiosamente democrático ou democratizante e até anarquizante, no amalgamento de raças e culturas e, até certo ponto, de tipos regionais, dando-se uma espécie de despedaçamento das formas mais duras, ou menos plásticas, por excesso de trepidação ou inquietação de conteúdos. ${ }^{15}$

A adoção do conceito de cultura em lugar do conceito de raça para explicar as relações raciais no Brasil não gerou necessariamente uma mudança na crença da inferioridade do negro na sociedade brasileira, apenas a tornou reversível, mas representou uma visão importante para a incorporação de mestiços e negros nos espaços econômicos, simbólicos e ideológicos da nação, inclusive com a reivindicação de direitos civis e sociais - o que Guimarães mostra com a atuação do Teatro Experimental Negro, criado em 1945 por Abdias do Nascimento. Nesse sentido, há um consenso racial-democrático, como refere o autor, na ideia de democracia racial: para Freyre e outros nacionalistas ela era prova da excelência da cultura luso-tropical e, para os representantes do movimento negro, era um ideal a ser atingido. ${ }^{16}$

Com o golpe militar de 1964 e o regime político que se seguiu, há um rompimento de tal compromisso, evidenciando uma cisão que já transparecia nas diferentes posições em relação ao colonialismo português na África e quanto ao movimento de identidade cultural africana. Florestan Fernandes, no seu diálogo com
13. Mattos (2016, p. 10).

14. Guimarães, op. cit., p. 147.

15. Freyre (1936, p. 355) apud Guimarães, op. cit., p. 152.

16. Guimarães, op. cit., p. 149-150. 
17. Fernandes (1965, p. 205) apud Guimarães, op. cit., p. 155.

18. Guimarães, op. cit., p. 147.

19. Saillant, op. cit., p. 26-27.

20. Ibid.

21. "Ações afirmativas são políticas focais que alocam recursos em benefício de pessoas pertencentes a grupos discriminados e vitimados pela exclusão socioeconômica no passado ou no presente. Trata-se de medidas que têm como objetivo combater discriminações étnicas, raciais, religiosas, de gênero ou de casta, aumentando a participação de minorias no processo político, no acesso à educação, saúde, emprego, bens materiais, redes de proteção social e/ou no reconhecimento cultural" (O que são..., 2011).
Freyre, constrói a ideia de "democracia racial" não como ideal, mas como mito usado de mecanismo social para defesa dos "ideais 'aristocráticos' da 'raça dominante" ${ }^{\prime \prime} .17$

A denúncia da democracia racial como mito se dá, portanto, no contexto das críticas à farsa da democracia política e passa a ser a principal arma ideológica dos movimentos negros para ampliar sua participação na sociedade brasileira nos anos 1980, seja em termos materiais ou culturais. ${ }^{18}$ Apesar das mudanças contemporâneas, não é difícil afirmar que ainda hoje essas noções fazem parte das visões de mundo dos brasileiros em geral e são reproduzidas pela mídia, em narrativas oficiais do Estado e mesmo no sistema educacional.

Na Conferência de Durban, em 2001, pela primeira vez a escravidão foi considerada crime contra a humanidade. Saillant relata que atualmente as reparações fazem parte das medidas de justiça transicional, ou seja, referentes ao conjunto de medidas políticas e judiciais utilizadas como reparação das violações de direitos humanos. A autora afirma que as reparações podem ser: compensações financeiras, restituição de bens, reabilitação de vítimas, procura e restabelecimento da verdade histórica, e garantia de não repetição do mal; mas também podem ter caráter simbólico, como: desculpas públicas, pedidos de perdão que reconheçam os sofrimentos causados às vítimas, e também ações ligadas às artes, à espiritualidade e à ritualidade. Uma vez que a justiça transicional está ligada ao restabelecimento do Estado de direito e é o Estado que declara e enquadra as medidas de reparação, Saillant ressalta que há um limite para a aplicação dessas medidas no caso da escravidão, que foi anterior ao arcabouço jurídico da justiça transicional. ${ }^{19}$

Além disso, a autora questiona se as reparações concedidas pelo Estado estão gerando reconhecimento individual e coletivo do ponto de vista das vítimas. Sendo assim, ela pensa em reparações diferentes das feitas pelo Estado, incluindo reparações simbólicas que caminham junto com o reconhecimento social. Daí se destaca a importância de encontrar o entrelaçamento das dimensões jurídicopolíticas e culturais das reparações. ${ }^{20}$

No Brasil, principalmente a partir de 2003, pedidos de reparação foram concretizados na forma de ações afirmativas, ${ }^{21}$ num contexto político em que o governo era mais afeito às demandas dos movimentos negros. Várias ações reparadoras surgem: a criação da Secretaria de Promoção das Políticas de Igualdade Racial (Seppir), em 2003; a Lei n 10.639/2003, que obriga o ensino da história da África e da cultura afro-brasileira e indígena nas escolas públicas; o Decreto n 4.887/2003, que regulamenta o artigo 68 do Ato das Disposições Constitucionais Transitórias (ADCT) e operacionaliza a titulação de terras quilombolas; e a Lei $n^{\circ} 12.711 / 2012$, que permite a reserva de $50 \%$ das vagas nas 59 universidades 
e 38 instituições federais para pessoas de cor ou em situação de pobreza. ${ }^{22}$ Percebese uma opção que passa principalmente por ações estruturantes no campo da educação, de forma a fornecer meios para que esses grupos saiam da condição de pobreza e quase-cidadania. "Tudo isso influenciou uma nova cultura política nas instâncias de poder e é resultado de décadas de ação social de militantes com o objetivo de incluir a agenda dos afro-brasileiros nas agendas de governo". ${ }^{23}$

Anteriormente, o reconhecimento constitucional dos territórios quilombolas (as comunidades de remanescentes de quilombo) e a previsão de regularização fundiária das terras tradicionalmente ocupadas por esses grupos foi um dos primeiros dispositivos legais no Brasil a ser considerado uma ação de reparação. Mas tais ações não podem ser limitadas somente ao campo político-legal. Podemos pensar também, como demonstra Saillant, ${ }^{24}$ nas "reparações vindas de baixo", isto é, nas ações coletivas que não esperam o reconhecimento social do Estado e do direito. São formas de se tornar visível socialmente, de forma positiva, tanto individual como coletivamente.

Desse modo, é possível pensar em políticas governamentais de patrimônio ${ }^{25}$ como esferas que articulam o reconhecimento nas suas dimensões cultural e jurídico-política. A patrimonialização ${ }^{26}$ é uma forma de reconhecimento da cultura e da história de um grupo pelo Estado e, muitas vezes, pela comunidade internacional, como no caso dos patrimônios reconhecidos pelas convenções da Organização das Nações Unidas para a Educação, a Ciência e a Cultura (Unesco), associando restauração, valorização, preservação, salvaguarda e produção de conhecimentos. Logo, podemos pensar nesse campo como parte das ações de reparação simbólicas e políticas. As políticas de patrimônio mobilizam dinâmicas que ligam Estado, sociedade civil e comunidades detentoras de patrimônio; nesse sentido, a luta pela constituição de um patrimônio afrobrasileiro organizada no país desde os anos 1980 gerou ações e processos no campo das políticas governamentais que podem ser pensadas como reparações.

Na perspectiva de Axel Honneth, há processos de reparações que articulam coletiva e explicitamente o reconhecimento jurídico-político e o reconhecimento cultural. As mudanças em andamento no campo do patrimônio vêm reforçar uma tal sinergia no espaço público. ${ }^{27}$
22. A primeira das universidades públicas a criar cotas raciais foi a Universidade do Estado do Rio de Janeiro (Uerj), em 2001 (Lei $\mathrm{n}^{\circ}$ 3.708/2001).

23. Cicalo (2016, p. 61).

24. Saillant, op. cit.

25. Segundo Lima e Castro (2015, p. 35), "as políticas governamentais devem ser entendidas como planos, ações e tecnologias de governo formuladas não só desde organizações administrativas de Estados nacionais, mas também a partir de diferentes modalidades de organizações que estão fora desse âmbito mas que exercem funções de governo. Pensamos aqui em ONGs e movimentos sociais, assim como em organismos multilaterais de fomento e de cooperação técnica internacional para o desenvolvimento".

26. Neste artigo, considera-se a patrimonialização como uma prática cultural de atribuição de valor a objetos, bens e práticas culturais, e a eleição destes como patrimônios culturais, representantes de uma coletividade e dignos de reconhecimento público. Esse processo é composto pela articulação de decisões políticas, estratégias sociais e práticas culturais.

27. Saillant, op. cit., p. 45. 
28. Hobsbawm; Ranger (2012).

29. Anderson (2008).

30. Gonçalves (1996).

31. Nos anos finais da década de 1930 , no regime do Estado Novo, o Brasil passou a ter uma política cultural voltada para a construção de uma identidade unificada de nação. Diversas leis e instituições governamentais foram criadas com o objetivo de possibilitar uma intervenção sistemática do Estado no imaginário nacionalista da sociedade. Em 1937 foi criado o Serviço do Patrimônio Histórico e Artístico Nacional (Sphan) e promulgado o Decreto-Lei $n^{\circ} 25$, de 30 de novembro, organizando a proteção do patrimônio histórico e artístico nacional. Nesse contexto, tínhamos um campo intelectual nacionalista associado ao movimento modernista que pensava tradição e modernidade de forma associada e conformou o discurso sobre o patrimônio histórico e artístico no Brasil (Chuva, 2003).

\section{Ibid.}

33. Arantes (1996, p. 9).

\section{PATRIMÔNIO, RECONHECIMENTO SOCIAL E REPARAÇÃO: OS ANOS 1980 E AS DEMANDAS PARA A CONSTITUIÇÃO DE UM PATRIMÔNIO AFRO-BRASILEIRO}

Como já amplamente debatido, a gênese do patrimônio histórico e artístico está atrelada à ideia de nação e à formação dos Estados nacionais, resultantes de processos, ao longo dos séculos XVII, XVIII e XIX, que envolveram disputas e estratégias diversas para estabelecer um sentimento de cultura partilhada entre os membros da pátria. A identidade nacional dependeu, sobretudo, do reconhecimento de um "passado comum", sustentado por "tradições inventadas"28 ou reapropriadas, mitos fundadores, lendas de tradição oral e versões oficiais da história no espaço geograficamente delimitado do Estado-nação. Os bens que formam o patrimônio histórico e artístico viriam objetivar, legitimar e conferir realidade à "comunidade imaginada" 29 que é a nação, materializando a sua ancestralidade. ${ }^{30}$

pensamento que se consolidou em relação ao patrimônio no Brasil constituía a nação brasileira, afastando-se dos regionalismos no sentido de possibilitar que o país pertencesse ao rol das nações modernas. Partindo da crença na universalidade da arte e da cultura, o grupo do Serviço do Patrimônio Histórico e Artístico Nacional (Sphan) ${ }^{31}$ valorizou o passado colonial, que representava as "origens" da nação, de matriz portuguesa, a partir da qual, no entanto, se configuraria um universo típico do Brasil. A produção artística do Barroco mineiro foi considerada a primeira genuinamente brasileira, sendo enquadrada na classificação tradicional da história da arte do mundo ocidental. ${ }^{32}$

Como visto, nas duas últimas décadas do século XX houve a afirmação dos multiculturalismos e a valorização da diferença a partir de novas categorias étnicas, religiosas e de gênero que se descolam da ideia de uma comunidade nacional homogênea. A discussão da questão nacional foi associada à ideia de que identidade e diversidade culturais são inseparáveis, e a noção de pluralismo cultural se atrelou ao reconhecimento da coexistência de diversas identidades culturais e tradições associadas a grupos sociais específicos.

As discussões sobre a cidadania passaram a se articular com práticas e concepções de identidade social que descentraram "princípios de estruturação universalizantes (como os de classe e nação) fortalecendo politicamente as minorias raciais, étnicas ou de gênero e suas alianças transnacionais. ${ }^{33}$

Nesse processo, a busca por reconhecimento social passa pela identificação com memórias coletivas particulares, que lutam por legitimidade no discurso 
histórico oficial, por representação política e por direitos. Tal fenômeno provocou uma reorientação dos discursos e estratégias das instituições associadas à preservação dos patrimônios culturais, que passaram a ser apropriadas como instrumento de construção de cidadania e afirmação social da identidade de grupos que demandam visibilidade e acesso a direitos.

Tratar das políticas de patrimônio no Brasil com foco no tema do reconhecimento social e da reparação requer iluminar o contexto de redemocratização do país na década de 1980, após a ditadura civil-militar. A valorização do patrimônio cultural naquela época esteve profundamente articulada com as disputas de memória na sociedade brasileira. Com o ressurgimento dos movimentos sociais, novos agentes, para além da burocracia e dos intelectuais, demandavam participação no campo das políticas patrimoniais, e o patrimônio passa a ter papel testemunhal das temporalidades que compõem as múltiplas experiências vividas individual e coletivamente na sociedade brasileira, tornando-se, assim, importante instrumento do reconhecimento de grupos sociais e da reelaboração de identidades coletivas. ${ }^{34}$

Foi no bojo desse processo que se passou a discutir com mais afinco a democratização da preservação de bens culturais e a ampliação do próprio conceito de patrimônio, conforme escreve Gilberto Velho em 1984, na Revista do Patrimônio:

A ampliação do próprio conceito de patrimônio cultural e o enriquecimento e flexibilização dos meios e instrumentos de que dispomos fazem parte de um projeto mais amplo, a longo prazo, de democratização da sociedade brasileira. Está em jogo a noção de cidadania, a questão dos direitos humanos, assim como, necessariamente, a questão fundamental da memória de uma nação. ${ }^{35}$

Assim, os debates em torno da memória nacional ganham destaque e se realizam em instâncias diferenciadas, articulando as narrativas patrimoniais dos movimentos sociais e os contextos intelectuais. Nesse processo de reelaboração de paradigmas de representação da nacionalidade, contribuiu o fortalecimento dos movimentos negros do país ao longo da década de 1980, ganhando destaque as disputas em torno da violência de Estado contra as populações negras e tradicionais. ${ }^{36}$ Há um deslocamento da memória pública em relação à escravidão e à abolição, mobilizando-se a ideia de "dívida histórica" e as expectativas de reparação social e cultural. Além disso, a figura dos quilombos ganha centralidade política na afirmação de uma "identidade negra" e na difusão da memória da luta dos escravos contra a escravidão, opondo-se à visão, celebrada na época imperial e posteriormente, da abolição como um ato de generosidade da família real.
34. Fonseca (2005); Nogueira (2008).

35. Velho (1984, p. 39).

36. Heymann; Arruti (2012). 
37. Domingues; Gomes (2013, p. 7-8).

38. Ibid., p. 10.

39. Ibid., p. 12-13.

40. Serviço do Patrimônio Histórico e Artístico Nacional (Sphan) foi a primeira denominação do órgão federal de proteção ao patrimônio cultural brasileiro, hoje Instituto do Patrimônio Histórico e Artístico Nacional (Iphan).

41. Fonseca (2005, p. 150151).
Domingues e Gomes dividem as visões tradicionais de intelectuais e acadêmicos sobre quilombos, até os anos 1980, em dois tipos: uma visão culturalista, que teve primazia dos anos 1930 a 1950 e pensou os quilombos como resistência cultural; e uma visão materialista, que ganhou força já nos anos 1960 e 1970 e criticava as teses de uma escravidão branda no Brasil, propostas pelas interpretações de Gilberto Freyre. ${ }^{37}$ É importante ressaltar que desde os anos 1970 houve uma revalorização da ideia de quilombo no imaginário social brasileiro e nas narrativas construídas pelos movimentos sociais, tornando-o símbolo do processo de construção e reafirmação política, social, cultural e identitária do movimento negro na contemporaneidade, e convertendo-o em "paradigma para a formação da identidade histórica e política de segmentos negros no Brasil". ${ }^{38}$

Além disso, os autores mostram que nos domínios do movimento negro no início das décadas de 1980, com a consolidação do Movimento Negro Unificado (MNU), "em vez de um projeto 'libertador' de cunho nacionalista, defendia-se uma perspectiva internacionalista, para não dizer pan-africanista, que combinasse os embates de 'raça' e 'classe' e estabelecesse conexão com os movimentos emancipatórios no Caribe, nos Estados Unidos e na África". ${ }^{39}$

Institucionalmente, no Sphan, desde a saída de Rodrigo Melo Franco de Andrade de sua presidência, em 1967,40 as mudanças em relação às práticas de preservação caminharam no sentido de apresentá-las como compatíveis com o processo de desenvolvimento e com os novos parâmetros internacionais de preservação. A criação do Centro Nacional de Referência Cultural (CNRC) por Aloísio Magalhães, em 1975, que buscava entender as diversas formas de produção cultural e seus modos de circulação e consumo nas comunidades e grupos locais, foi importante nesse contexto.

À diferença das instituições já existentes voltadas para o conhecimento e a proteção da cultura brasileira, o CNRC não se propunha a coletar bens, e sim a produzir referências - com o recurso às ciências sociais, à documentação e à informática - que pudessem ser utilizadas no planejamento econômico e social [...]. O problema que serviu de ponto de partida à criação do CNRC - a falta de um caráter nacional no produto brasileiro - remetia, como ocorrera nos anos 20 com os modernistas em relação à produção cultural brasileira, à questão da tradição. Em 1975, o grupo inicial do CNRC considerava que o que faltava para conferir caráter ao produto e à nação brasileiros era uma tradição que estivesse, não apenas cristalizada, internalizada, mas, sobretudo, viva, que fosse apreendida em sua dinâmica e em sua pluralidade. Acreditava-se que era nessas características que residia seu potencial criativo. ${ }^{41}$

Mais tarde, no período de redemocratização do país, noções como "participação da comunidade" e "direitos culturais" se tornaram importantes 
recursos para a legitimação de uma política cultural que se pretendia democrática. ${ }^{42} \bigcirc$ CNRC foi integrado em 1979 à Fundação Nacional PróMemória. ${ }^{43}$ Com a junção Sphan/Pró-Memória, sob a direção de Aloísio Magalhães até seu falecimento, em 1982, houve a ampliação e diversificação dos quadros profissionais do órgão, o que foi importante para alargar a noção de patrimônio e para uma representação mais plural da cultura brasileira. ${ }^{44}$

Segundo Chuva, três noções criadas ou ressemantizadas entre 1982 e 2002 são centrais para as mudanças no campo das políticas federais de patrimônio cultural, quais sejam: referência cultural, quilombo e cidade-documento. "Ao refletir sobre a apropriação dessas noções nos anos 1980 e 1990, veremos a configuração de novos objetos passíveis de se tornarem patrimônio, novos problemas a serem enfrentados e novas abordagens sobre antigos objetos patrimoniais" ${ }^{45}$

A noção de referência cultural, inicialmente formulada na década de 1970, como visto, foi fundamental para incluir grupos sociais como legítimos sujeitos de atribuição de valor patrimonial, conforme expresso nos artigos 215 e 216 da Constituição Federal de 1988 (CF/88). $\bigcirc$ artigo 216, no seu parágrafo primeiro, afirma: "O poder público, com a colaboração da comunidade, promoverá e protegerá o patrimônio cultural brasileiro, por meio de inventários, registros, vigilância, tombamento e desapropriação, e de outras formas de acautelamento e preservação". ${ }^{46}$

Dois tombamentos ocorridos nos anos 1980 são recorrentemente apontados como casos emblemáticos da luta pela inclusão de representações de grupos identitários afro-brasileiros no patrimônio cultural formalmente reconhecido no Brasil: o do Terreiro da Casa Branca (llé Axé lyá Nassô Oká), em 1984, e o da Serra da Barriga, em 1986 - "local onde se estabeleceu no século XVII o Quilombo dos Macacos, sede do Quilombo dos Palmares". 47 Antropólogo, professor da Universidade Federal da Bahia e intelectual com importante atuação no campo das políticas públicas de patrimônio nesse período, Ordep Serra afirma:
42. Id. (1996).

43. "De 1979 a 1990 o atual Instituto do Patrimônio Histórico e Artístico Nacional (Iphan) ficou conhecido pela sigla Sphan/Pró-Memória. Ao longo desse período mudanças significativas ocorreram na trajetória das políticas públicas voltadas para a área cultural envolvendo a instituição federal de preservação do patrimônio cultural. Essa forma de organização, a Sphan/Pró-Memória, correspondeu a três momentos distintos dessa trajetória: a estrutura de secretaria foi adotada para o órgão federal de proteção ao patrimônio duas vezes, de 1979 a 1981 e de 1985 a 1990 , enquanto a de subsecretaria foi aplicada nesse intervalo, ou seja, de 1981 a 1985" (Rezende et al., 2015).

44. Para entender melhor a sequência de mudanças nos arranjos administrativos e as diversas nomenclaturas do que hoje é o Iphan, cf. Thompson (2015).

45. Chuva (2017, p. 90-91). 46. Brasil (1988b, grifo meus).

47. Instituto do Patrimônio Histórico e Artístico Nacional (1982, v. 1, f. 1).

48. Serra (2005, p. 170).
Uma terceira etapa nas relações entre terreiros e o Estado viria a inaugurar-se na década de 1980, quando se deu (em algumas instâncias) o reconhecimento do significado histórico desses centros de culto enquanto depositários da memória de um importante segmento da população brasileira, e se afirmou o valor do acervo de bens culturais neles encerrados: notáveis ilê axé tornaram-se, então, objeto de iniciativas de preservação que passaram a contemplar o patrimônio formado por monumentos e símbolos do povo-de-santo. [...] o processo teve desdobramentos etnopolíticos, envolvendo a "production des identités"; acarretou redefinições institucionais, reconfigurações do panorama intelectual e a geração de novos modelos de policy-making no campo da cultura. ${ }^{48}$ 
49. Velho (2006, p. 240).

50. Saillant, op. cit., p. 41.

51. Chuva (2017, p. 96).

52. Serra, op. cit. p.171.

53. Instituto do Patrimônio Histórico e Artístico Nacional (1982, v. 1, f. 1)

54. Olympio Serra, antropólogo da Universidade Federal da Bahia, participou, juntamente com o também antropólogo Ordep Serra, do Projeto de Mapeamento de Sítios e Monumentos Religiosos Negros da Bahia (MAMNBA). O projeto foi executado a partir de convênio celebrado entre Fundação Nacional Pró-Memória e a prefeitura de Salvador.

55. Segundo Serra (2005, p. 173), o projeto era "de início voltado para o resgate de uma memória indígena: envolveu a indexação e microfilmagem de rica documentação em depósito no Museu do Índio. Mas tinha ambição maior, a saber, corrigir um sério defeito da política cultural brasileira: reparar seu etnocentrismo, sua fixação eurocêntrica. Logo passou, também, a promover iniciativas voltadas para a defesa dos valores do patrimônio negro do Brasil".
Vários intelectuais consideram a valorização patrimonial de terreiros o começo de uma política de reparos à violência histórica que marcou a comunidade religiosa afro-brasileira, na Casa Branca e noutros espaços similares por todo o Brasil, desde o início da Primeira República. ${ }^{49}$ Como ressalta Saillant,

as religiões afro-brasileiras, como o candomblé, foram elaboradas à sombra da escravidão como espaço de memória e elaboração cultural sobre a nova realidade dos indivíduos escravizados no Brasil. Por meio dos cultos aos ancestrais se estabeleceu um vínculo simbólico entre os ancestrais e a nova terra e entre os sobreviventes e os mortos da escravidão. O espaço religioso afro-brasileiro é certamente o primeiro ato de reparação, mas esse ato não veio da autoridade política, mas de uma autoridade religiosa coletiva que soube se impor com o tempo desde o século XIX. ${ }^{50}$

Já a discussão sobre a noção de quilombo e sua inserção no campo do patrimônio, segundo Chuva, "contribuiu fortemente com os novos paradigmas que colocaram a temática do patrimônio como direito e como instrumento de reparação". 51

Na verdade, a temática dos quilombos chegou ao Sphan/Pró-Memória em 1981 , antes da promulgação da CF/88, com o pedido de tombamento da Serra da Barriga pelo Conselho Geral do Memorial Zumbi. A trajetória do processo de tombamento articulou intelectuais, principalmente vinculados ao movimento negro, com múltiplas inserções em instituições governamentais e espaços acadêmicos, levando à inscrição do bem nos Livros do Tombo Histórico e do Tombo Arqueológico, Etnográfico e Paisagístico em 1986.

No ano de 1980, verificou-se na Fundação Nacional Pró-Memória uma intensa movimentação, antes disso absolutamente inusitada nos órgãos de cultura nacionais. $\bigcirc$ coordenador do Projeto Etnias mobilizou lideranças negras de todo o país e promoveu uma histórica reunião em União dos Palmares, Alagoas, dando origem ao Memorial Zumbi. Este se instalou sob a presidência do antropólogo Olympio Serra, reunindo no seu Conselho Geral representantes de diversas organizações antirracistas, pessoas e grupos envolvidos nas lutas pelos direitos humanos, membros e líderes de comunidades negras tradicionais, várias entidades da sociedade civil. Seu Conselho Deliberativo promoveu os estudos e implementou as medidas que possibilitariam o tombamento da Serra da Barriga, em 1985.52

Processo de Tombamento n 1.069-T-82, disponível no Arquivo Noronha Santos, ${ }^{53}$ mostra que o pedido foi encaminhado em 2 de julho de 1981 para Aloísio Magalhães em oficio assinado por Olympio Serra ${ }^{54}$ - coordenador do Projeto Etnias, da Sociedade Nacional da Fundação Nacional Pró-Memória ${ }^{55}$ e 
presidente do Conselho Deliberativo do Memorial Zumbi - em nome do Conselho Geral do Memorial Zumbi. ${ }^{56} \bigcirc$ ofício em questão assim solicita:

O tombamento da área aventada para que nela se instale o Memorial Zumbi: Parque Histórico Nacional destina-se não só a preservação do sítio histórico, mas também a cultivar a memória de todos que, então, lutaram na busca de sua liberdade. Tal proposta vem de encontro às aspirações de grande número de brasileiros preocupados em preservar a Memória Nacional não apenas em suas manifestações visíveis, mas também no conjunto de seus símbolos, para que estes atuem como fonte de referência para as novas gerações. Palmares, em relação aos demais Quilombos, ocupa lugar de destaque não só por ter resistido por quase um século, mas por ter concretizado o ideal de pluralidade étnica, dele tendo participado, lado a lado, negros, índios, brancos e mestiços. ${ }^{57}$

Ao pedido se seguia uma representação espacial da área de 2.200 hectares $^{58}$ solicitada para compor o Parque Histórico Nacional. $\bigcirc$ volume 1 do processo de tombamento em questão é composto por 228 folhas, das quais a grande maioria é preenchida de assinaturas em apoio ao pedido. Ao todo foram acrescidas 5.804 assinaturas de membros de grupos ligados aos movimentos negros, grupos de pesquisa, universidades, intelectuais e políticos conhecidos pela produção acadêmica e atuação política vinculadas ao papel dos afrodescendentes na sociedade brasileira. Entre essas assinaturas, temos como principais apoiadores pessoas como: Joel Rufino dos Santos, Ordep Serra, Lélia Gonzalez, Abdias do Nascimento, Elisa Larkin Nascimento e Olympio Serra, dando o tom da visão sobre o quilombo que acompanhou essa solicitação. ${ }^{59}$

No processo, são explicitados em documento enviado pelo Conselho Geral do Memorial Zumbi os antecedentes do pedido de tombamento. É informado que em junho de 1979 a Fundação Projeto Rondon solicitou à Empresa Brasileira de Turismo avaliação de projeto para um "Parque Histórico do Zumbi", e em outubro do mesmo ano foi estabelecido um convênio entre o governo de Alagoas, a Secretaria de Planejamento do estado, a Empresa Alagoana de Turismo, o Instituto Histórico de Alagoas, a prefeitura de União dos Palmares, a prefeitura de Maceió, a Universidade Federal de Alagoas (Ufal), a Fundação Projeto Rondon e a Secretaria de Educação e Cultura de Alagoas. ${ }^{60}$

Em 1980, segundo o documento, foi realizado por iniciativa da Ufal, com patrocínio da Coordenação de Aperfeiçoamento de Pessoal de Nível Superior (Capes) e da Fundação Nacional Pró-Memória, o Seminário para a criação do Parque Histórico Nacional Memorial de Zumbi. ${ }^{61}$ Compareceram ao evento setenta pessoas, entre representantes de instituições governamentais e comunidades negras,
56. O Conselho Geral do Memorial Zumbi contava com dezessete membros, sendo dez deles de entidades de cultura negra presentes no Seminário de Maceió e pessoas cujos trabalhos eram relativos à situação do negro no Brasil (Boletim Sphan/Pró-Memória, 1981a, p. 10).

57. Instituto do Patrimônio Histórico e Artístico Nacional (1982, v. 1, f. 1).

58. A área proposta para tombamento teve uma diminuição significativa, passando dos 2.200 hectares iniciais para somente a parte mais acantilada da Serra da Barriga, devido ao desenvolvimento dos estudos iniciais para implantação do Memorial Zumbi e também ao pedido de impugnação do tombamento proposto pelos proprietários da Usina Laginha, que possuía terreno na área demarcada.

59. "Para Hamilton Cardoso, Lélia Gonzalez, Beatriz do Nascimento, Clóvis Moura, Joel Rufino, entre outras lideranças e intelectuais afro-brasileiros, o quilombo foi o principal modelo de organização social e luta política do negro pela liberdade. Bebendo nas narrativas marxistas, viam os quilombos como lugares habitados por todos os 'oprimidos' do sistema escravista - sobretudo negros, mas também índios $\mathrm{e}$ brancos pobres -, os quais viviam com liberdade, igualdade e abundância, afinal, as terras e o fruto do trabalho seriam coletivizados. Ao desenvolverem uma agricultura diversificada, oposta à monocultura, os quilombos produziriam excedentes que eram vendidos ou trocados por outras mercadorias com os vizinhos das comunidades quilombolas, constituindo uma rede de cooperação e solidariedade mútua. Por essas razões, os quilombos te- 
riam se convertido numa ameaça à ordem vigente, na medida em que forjaram, na prática, um modelo de sociedade alternativa" (Domingues; Gomes, op. cit., p. 13).

60. Instituto do Patrimônio Histórico e Artístico Nacional (1982).

61. Ibid.

62. Joel Rufino dos Santos, falecido em 2015, foi um historiador, professor e escritor tido como referência nos estudos da cultura afro-brasileira. "Nasceu no Rio de Janeiro em 1941. É doutor em Comunicação e Cultura pela Universidade Federal do Rio de Janeiro. Conhecido a partir de 1960 , quando participou da elaboração da revolucionária coleção de livros didáticos 'História Nova', que o levou algumas vezes aos cárceres da ditadura militar. Tem incursões em várias formas de expressão escrita, do livro didático ao romance histórico, passando também pelo teatro, pelos roteiros de televisão e pela literatura infantil. Foi subtitular da Secretaria Extraordinária de Defesa e Promoção das Populações Negras do Estado do Rio de Janeiro (19911992) e presidiu a Fundação Cultural Palmares do Ministério da Cultura. O historiador e escritor é referência no pensamento e na atuação contra o racismo no Brasil. Rufino foi um dos intelectuais perseguidos, após o Golpe de Estado de 50 anos atrás (1964)" (Joel..., 2018).

63. "O Núcleo de Estudos Afro-Brasileiros foi criado em 1981 com o objetivo básico de criar espaços para os estudos da temática negra, no âmbito acadêmico da Ufal. $\mathrm{O}$ professor Décio Freitas foi o primeiro diretor do Núcleo, na época, conhecido como Centro de Estudos Afro-Brasileiros, momento de grande e seu resultado foi o documento "Conclusões do primeiro Seminário para a criação do Parque Histórico Nacional Memorial de Zumbi", além da própria constituição do Conselho Geral do Memorial Zumbi. É interessante perceber a multiplicidade de parcerias institucionais e agentes atuantes nesse caso para a criação e valorização do bem patrimonial, tão conectado às novas formas de legitimação das políticas culturais no contexto dos anos 1980.

No número 12 do Boletim Sphan/Pró-Memória, de maio/junho de 1981, ou seja, antes do envio do pedido de tombamento para o secretário Aloísio Magalhães, há uma notícia sobre a realização do Seminário e a constituição do referido Conselho Geral, com destaque para Olympio Serra como presidente e Joel Rufino dos Santos ${ }^{62}$ como secretário. Também é informado que as reuniões para definição do regimento interno da organização ocorreram nos dias 29 e 30 de abril de 1981, na sede do Sphan/Pró-Memória em Brasília, mostrando as importantes conexões que havia na época entre intelectuais vinculados ao movimento negro, universidades e instituições governamentais. Além disso, refere-se o apoio ao Conselho Geral por parte do Centro de Estudos Afro-Brasileiros, ${ }^{63}$ criado nessa mesma época na Ufal, com sede na Casa de Jorge de Lima, em União dos Palmares. ${ }^{64}$

Outro fato importante é a ocorrência anual, na Serra da Barriga, de peregrinações cívicas no dia 20 de novembro, escolhido pelos movimentos sociais como Dia Nacional da Consciência Negra ${ }^{65}$ por ser considerado a data do assassinato de Zumbi, o importante líder de Palmares. Ordep Serra observa:

[...] já em 1980, a primeira reunião do Memorial deu início a um trabalho de resgate daquele sítio, originando uma romaria cívica ao local em que teve sede o quilombo de Zumbi. Da Bahia partiram rumo a Palmares centenas de jovens ligados aos blocos afros e a diversos grupos organizados da comunidade negra. Desde aquela primeira reunião de 1980, a peregrinação cívica a Palmares se repete todos os anos, com a participação de brasileiros de todos os quadrantes, e até de estrangeiros, que para lá convergem no dia 20 de novembro. O gesto pioneiro de 1980, início de uma campanha nacional, ajudou a fixar na memória do país a data de 20 de novembro como Dia Nacional da Consciência Negra. ${ }^{66}$

Na exposição de motivos enviada pelo Conselho Geral do Memorial Zumbi ${ }^{67}$ para o tombamento federal, temos como fundamentação legal o artigo $1^{\circ}$ do DecretoLei n ${ }^{\circ}$ 25/1937, que refere fatos memoráveis da história do Brasil, além do DecretoLei n 84.017/1979, que aprova o Regulamento dos Parques Nacionais Brasileiros, lançando mão da ideia de Zona Histórica Cultural: "é aquela onde são encontradas manifestações, históricas, culturais ou arqueológicas que serão preservadas, estudadas, restauradas e interpretadas para o público, servindo à pesquisa, educação 
e ao uso científico". 68 Havia uma expectativa muito grande de que os estudos arqueológicos a serem realizados na área pudessem contribuir fortemente para reescrever a história do Brasil, principalmente da escravidão e da abolição.

Na justificativa desse documento é interessante notar a importância da parceria entre as instituições governamentais, as comunidades acadêmica e negra, mostrando as inserções sociais dos agentes do pedido de tombamento. Em relação às instituições governamentais, são ressaltados elementos muito próximos do ideário da Fundação Nacional Pró-Memória, herdeira do CNRC, a saber: "[o] Desenvolvimento brasileiro só será autêntico na medida [em] que estiver fundamentado sobre elementos próprios do nosso sistema cultural [...] reconhecendo-se também as culturas marginalizadas".69 Quanto à comunidade acadêmica, atribuiu-se importância à possibilidade de o local ser ponto de convergência de todos os "estudiosos da história dos movimentos negros no Brasil, representando, ainda, um elo significativo na história das relações entre os povos da África e da América". Já para a comunidade negra, considerou-se o tombamento da Serra da Barriga o "primeiro passo para o resgate da sua história e consequentemente de sua personalidade [...] pedra fundamental de um Brasil democrático; pluricultural e multiétnico" .70

No mesmo ano, no número 15 do Boletim Sphan/Pró-Memória, outra notícia tratou da inauguração do marco de construção do Memorial Zumbi, cuja placa continha os dizeres: "Neste local se construirá um monumento - o Memorial Zumbi - em honra dos guerrilheiros palmarinos e de seu líder maior. Deverá se erguer como polo de luta pelo direito à história e pelo resgate dos heróis negros que dignificaram esse país" ${ }^{71}$ Referindo-se à reunião do Conselho Deliberativo e Geral do Memorial Zumbi realizada em 19 e 20 novembro de 1981, em Maceió, foram relatadas as articulações com Dora Alcântara, chefe do Departamento de Pesquisas e Tombamento do Sphan à época, e com Teresa Jorge Pádua, diretora do Departamento de Parques Nacionais do Instituto Brasileiro de Desenvolvimento Florestal (IBDF). ${ }^{72}$

Os pareceres dos técnicos do Sphan no processo mostram preocupação com a extensão da área a ser tombada, sua posterior gestão e utilização, a questão fundiária local e a articulação com o IBDF.73 Desse modo, em 1984 ○ tombamento ainda estava em andamento, o que gerou mais mobilização social para o atendimento do pedido. No volume 2 do processo há o registro de vários ofícios enviados para a Divisão de Conservação e Tombamento do Sphan por instituições de pesquisa e associações da sociedade civil e, inclusive, um da Câmara dos Deputados, do dia 19 de novembro de 1984, assinado pelo deputado federal Abdias do Nascimento. ${ }^{74}$ efervescência política, principalmente, para o movimento negro que tentava firmar suas principais reivindicações. [...] outros profissionais comprometidos com a temática negra também atuaram como dirigentes do Núcleo, deixando nele suas marcas e suas conquistas, como os professores Zezito de Araújo, Ângela Bahia Brito, Maria de Lourdes Lima, Max Luterman e Moisés Melo Santana" (Freire, 2015).

64 Boletim Sphan/Pró-Memória (1981a).

65. Domingues e Gomes (op. cit., p. 10) afirmam que, em 1974, o Grupo Palmares, do Rio Grande do Sul, sugeriu que o 20 de novembro, suposta data de morte de Zumbi dos Palmares, em 1695, passasse a ser comemorado como data nacional, contrapondo-se ao 13 de maio, de forma que a rememoração do passado fosse centrada na resistência heroica do Quilombo do Palmares.

66. Serra (2005, p. 174).

67. Instituto do Patrimônio Histórico e Artístico Nacional (1982, v. 2, f. 26-36).

68. Ibid., v. 2, f. 28.

69. Ibid., v. 2, f. 29.

70. Ibid.

71. Boletim Sphan/Pró-Memória (1981b, p. 10).

72. Fundado em 28 de fevereiro de 1967 e extinto em 22 de fevereiro de 1989.

73. Informação Técnica $n^{\circ}$ 113 (Instituto do Patrimônio Histórico e Artístico Nacional, 1982, v. 2, f. 17); Ofício $\mathrm{n}^{\circ} 755 / 81$ (ibid., v. 2, f. 46-47). 
74. "Abdias do Nascimento (Franca, SP, 1914 - Rio de Janeiro, RJ, 2011). Ator, diretor e dramaturgo. Militante da luta contra a discriminação racial e pela valorização da cultura negra. É responsável pela criação do Teatro Experimental do Negro (TEN), que atua no Rio de Janeiro entre 1944 e 1968. [...] A militância política de Abdias do Nascimento começa na década de 1930, quando integra a Frente Negra Brasileira, em São Paulo. [...] Dirige, entre 1948 e 1951, o jornal Quilombo, órgão de divulgação do grupo e de notícias de outras entidades do movimento negro. Realiza a Conferência Nacional do Negro, em 1949 e, o $1^{\circ}$ Congresso do Negro Brasileiro, em 1950. [...] Devido à perseguição política, em 1968 Nascimento parte para um exílio que dura treze anos. Com a dissolução do TEN, deixa de atuar e dirigir no teatro, e sua militância ganha outras direções. Fora do Brasil, atua como conferencista e professor universitário, publica uma série de livros denunciando a discriminação racial $\mathrm{e}$ dedica-se à pintura e pesquisa visualidades relacionadas à cultura religiosa afro-brasileira. Na volta ao país, investe na carreira política, assume cargo de deputado federal e senador da república pelo Partido Democrático Trabalhista (PDT), sempre reivindicando um lugar para a cultura negra na sociedade" (Abdias..., 2018).

75. Ata da $117^{a}$ reunião do Conselho Consultivo do Patrimônio Cultural (1985, p. 13v).

76. Ibid., p. 14 .

77. Meneses (2012, p. 25)
Na $117^{a}$ reunião do Conselho Consultivo do Patrimônio Cultural, realizada dia 18 de novembro de 1985, a relatora do processo, Maria Beltrão, ressaltou "ser Palmares local de resistência do grupo negro, lugar fundador, sonho de uma república negra". ${ }^{75}$ O subsecretário do Sphan/Pró-Memória na época, Ângelo Oswaldo de Araújo Santos, destacou o forte simbolismo que reveste a Serra da Barriga e ressaltou que o ato "vem ampliar o sentido e a importância do instituto do tombamento como instrumento apto a prestar serviços a todas as vertentes da cultura brasileira". 76

É interessante perceber o processo de invenção de tradição, objetivando a incorporação do sujeito negro na história oficial do país, com base em um ideário de identidade pluriétnica e multicultural da nação brasileira. $\bigcirc$ tombamento federal da Serra da Barriga, local do Quilombo dos Palmares, incorporou demandas por reparação simbólica do movimento negro dos anos 1980, baseado na construção de uma nova memória da nação, a partir de releituras da história e da retificação de fatos históricos. Nesse caso, o argumento é que as políticas governamentais de patrimônio cumpriram a importante tarefa de incorporar a dimensão cultural e jurídicopolítica do reconhecimento, tendo papel relevante na dimensão de reparação que a categoria "quilombo" ganhou na CF/88 e nas suas ressemantizações posteriores.

\section{PATRIMÔNIO, QUILOMBOS, RECONHECIMENTO E REPARAÇÃO}

No ano de 1988, a Constituição Federal Cidadã é promulgada com claros avanços jurídicos em relação ao patrimônio. Além da mudança da matriz do valor cultural do Estado para a sociedade e seus segmentos, ${ }^{77}$ as categorias "imaterial", "referência à identidade, à ação e à memória" e "registro" adentram o ordenamento jurídico brasileiro, implicando uma ampliação conceitual da noção de patrimônio, pensado agora por meio da categoria "patrimônio cultural".

Art. 215. O Estado garantirá a todos o pleno exercício dos direitos culturais e acesso às fontes da cultura nacional, e apoiará e incentivará a valorização e a difusão das manifestações culturais.

$\S 1^{\circ} \bigcirc$ Estado protegerá as manifestações das culturas populares, indígenas e afro-brasileiras, e das de outros grupos participantes do processo civilizatório nacional. [...]

Art. 216 . Constituem patrimônio cultural brasileiro os bens de natureza material e imaterial, tomados individualmente ou em conjunto, portadores de referência à identidade, à ação, à memória dos diferentes grupos formadores da sociedade brasileira, nos quais se incluem: I 
- as formas de expressão; II - os modos de criar, fazer e viver; III - as criações científicas, artísticas e tecnológicas; IV - as obras, objetos, documentos, edificações e demais espaços destinados às manifestações artístico-culturais; $V$ - os conjuntos urbanos e sítios de valor histórico, paisagístico, artístico, arqueológico, paleontológico, ecológico e científico.

$\S 1^{\circ} \bigcirc$ Poder Público, com a colaboração da comunidade, promoverá e protegerá o patrimônio cultural brasileiro, por meio de inventários, registros, vigilância, tombamento e desapropriação, e de outras formas de acautelamento e preservação.

$\S 2^{\circ}$ Cabem à administração pública, na forma da lei, a gestão da documentação governamental e as providências para franquear sua consulta a quantos dela necessitem.

$\S 3^{\circ} \mathrm{A}$ lei estabelecerá incentivos para a produção e o conhecimento de bens e valores culturais.

$\S 4^{\circ}$ Os danos e ameaças ao patrimônio cultural serão punidos, na forma da lei.

$\S 5^{\circ}$ Ficam tombados todos os documentos e os sítios detentores de reminiscências históricas dos antigos quilombos. [...]

Art. 68 [do ADCT]. Aos remanescentes das comunidades dos quilombos que estejam ocupando suas terras é reconhecida a propriedade definitiva, devendo o Estado emitir-thes os títulos respectivos. ${ }^{78}$

A CF/88, ao tratar da questão quilombola, passa a prever o tombamento de sítios e reminiscências históricas dos antigos quilombos ${ }^{79}$ e reconhece as terras ocupadas como propriedade definitiva dos remanescentes dessas comunidades, criando a obrigação de que sejam tituladas pelo Estado. ${ }^{80}$ As inovações no texto constitucional trazem para o campo de atuação governamental do patrimônio as políticas afirmativas e questões ligadas às dimensões jurídico-políticas das demandas por reparação.

Yussef Campos, na sua análise das discussões acerca do patrimônio cultural no processo constituinte, mostra que "questões indeléveis sobre a posse e a propriedade de terras, locais de práticas culturais e de vivência de valores e costumes - indispensáveis para a patrimonialização de bens culturais -, foram pontos polêmicos na Assembleia Nacional Constituinte" ${ }^{81}$

Veja que o mito das três raças, o mito das três raças no DNA da nação de cultura brasileira, a maldição das três raças, continua aqui. Mas não é certo que as pessoas não estivessem alertas para isso, tanto que no capítulo sobre os direitos indígenas houve avanços importantíssimos. Mas quanto ao tombamento dos "documentos e os sítios detentores de reminiscências históricas dos antigos quilombos"... Não se pode esquecer que 1988 é o ano do Centenário da Lei Áurea. Além disso, esse parágrafo esquece que o tombamento é um processo jurídico-administrativo extremamente complexo, que deve atender determinadas exigências, a primeira das quais é a precisa identificação de seu objeto. Um tomba-
78. Brasil (1988b, grifos meus).

79. Ibid., art. $216, \S 5^{\circ}$.

80. Ibid., ADCT, art. 68.

81. Campos (2017, p. 204). 
82. Arantes (2013) apud Campos (2017, p. 204-205).

83. Campos (2018, p. 99).

84. Domingues; Gomes, op. cit., p. 13-14.

85. Almeida (2008); Arruti (2011); Domingues; Gomes, op. cit.

86. Campos, 2017.

87. Arruti, op. cit.

88. Ibid., p. 285 mento genérico como esse cria expectativas, ao mesmo tempo que não atende a nenhuma; ele cria o direito e o dever de preservar uma categoria indefinida de bens. ${ }^{82}$

Além das dissonâncias em relação aos sentidos do tombamento, direitos culturais e territoriais são tratados separadamente no texto da Constituição, refletindo interesses políticos e econômicos no contexło da Assembleia Nacional Constituinte, o que gerou uma lacuna no ordenamento jurídico constitucional entre o patrimônio e o acesso à terra, num "descolamento do binômio lugar e território das práticas e bens culturais classificados como patrimônio". ${ }^{83}$ Essas dificuldades tiveram o efeito de postergar a regulamentação das normas constitucionais e, consequentemente, o efetivo atendimento das demandas das comunidades remanescentes de quilombos.

Como visto no tópico anterior, nos anos 1970 e 1980 a retórica do quilombo tornou-se importante instrumento para o movimento negro contra todas as formas de opressão. A incorporação gradual das comunidades negras rurais aos movimentos de afirmação racia| ${ }^{84}$ ocorreu por conta do contexto desenvolvimentista, que aumentou conflitos e disputas por terras no país. Nesse sentido, diversos autores ${ }^{85}$ apontam os Encontros de Comunidades Negras como marcos significativos. O primeiro, ocorrido no Maranhão em 1986, foi importante para a discussão sobre as "terras de preto" na Assembleia Nacional Constituinte, mas Campos ressalta que nesse fórum não houve a interpretação imediata de tais territórios como quilombos. ${ }^{86}$

Na verdade, Arruti ${ }^{87}$ mostra como o artigo 68 das disposições transitórias foi formulado segundo os movimentos negros urbanos, para os quais a metáfora do quilombo tinha centralidade, e que se desconhecia a dimensão da questão negra rural - daí a nomenclatura "comunidade remanescente de quilombo" ter ganhado destaque no texło constitucional, e não a expressão "comunidades negras rurais". Anteriormente, as populações negras rurais eram vistas pela história, pelos movimentos sociais e pelas políticas públicas como parte do campesinato, ${ }^{88}$ de modo que suas reivindicações e movimentos, nesse caso, não estavam ligados a uma política da diferença. A nova categoria adotada é de natureza jurídica e institui uma nova figura de direito.

Ao longo da década de 1990, embates acerca da ressemantização da categoria "quilombo" contaram com maior organização dos movimentos sociais ligados às comunidades negras rurais e com o respaldo de instituições acadêmicas, por meio de novas pesquisas antropológicas e historiográficas. Antropólogos adquiriram papel de relevo na confecção de laudos em procedimentos burocráticos de certificação de comunidades quilombolas e titulação de suas terras. Em 1994, a Associação Brasileira de Antropologia (ABA), a partir do Grupo de Trabalho Terra de Quilombo, expressov em documento um entendimento acerca do termo "quilombo" que teve o potencial de estabelecer parâmetros de atuação nesses campos. 
O termo quilombo tem assumido novos significados na literatura especializada e também para grupos, indivíduos e organizações. Ainda que tenha um conteúdo histórico, o mesmo vem sendo "ressemantizado" para designar a situação presente dos segmentos negros em diferentes regiões e contextos do Brasil. [...] Contemporaneamente, portanto, o termo não se refere a resíduos ou resquícios arqueológicos de ocupação temporal ou de comprovação biológica. Também não se trata de grupos isolados ou de uma população estritamente homogênea. Da mesma forma, nem sempre foram constituídos a partir de movimentos insurrecionais ou rebelados, mas sobretudo, consistem em grupos que desenvolveram práticas de resistência na manutenção e reprodução de seus modos de vida característicos num determinado lugar. [...] Nesse sentido, constituem grupos étnicos conceitualmente definidos pela antropologia como um tipo organizacional que confere pertencimento através de normas e meios empregados para indicar afiliação ou exclusão. [...] No que, diz respeito à territorialidade desses grupos, a ocupação da terra não é feita em termos de lotes individuais, predominando seu uso comum. A utilização dessas áreas obedece a sazonalidade das atividades [...], caracterizando diferentes formas de uso e ocupação do espaço que tomam por base laços de parentesco e vizinhança, assentados em relações de solidariedade e reciprocidade. ${ }^{89}$

Os desdobramentos do texto constitucional trouxeram um desafio institucional para os órgãos de patrimônio, que é o de gerir bens culturais vinculados a demandas de outros órgãos competentes, como o Instituto Nacional de Colonização e Reforma Agrária (Incra), a Fundação Cultural Palmares e, como vamos ver, também os órgãos ambientais. ${ }^{90}$ Dessa forma, um maior número de procedimentos burocráticos, negociações políticas e certo consenso acerca dos entendimentos da categoria "remanescente de quilombo" são necessários para a construção de políticas governamentais que atendam às normas constitucionais.

Entretanto, divergências importantes acerca dessa categoria nas diversas esferas institucionais, e principalmente a confusão relativa às atribuições dos órgãos governamentais envolvidos na certificação e titulação das "comunidades remanescentes de quilombo", até hoje dificultam o acesso à terra e a outros direitos desses grupos. Isso seria sanado somente com o Decreto $n^{\circ} 4.887 / 2003$, que, ao levar em conta o acúmulo das discussões em várias esferas da sociedade brasileira desde meados da década de 1990, acaba por estabelecer condições reais de exercício dos direitos previstos constitucionalmente para as "comunidades remanescentes de quilombo", articulando noções como território e territorialidade nas suas dimensões culturais. ${ }^{91}$

Com este decreto o Instituto Nacional de Colonização e Reforma Agrária (Incra) passou a ser o responsável pelo processo de regularização fundiária das comunidades quilombolas; restituiu a possibilidade de se realizarem desapropriações para este fim; incorporou o direito destas comunidades ao autorreconhecimento, em concordância com a Convenção 169 da OIT [Organização Internacional do Trabalho] e, finalmente, estabeleceu que a titulação das terras deve se dar em nome de entidade representativa da comunidade. ${ }^{92}$
89. Associação Brasileira de Antropologia (1994, p. 1-3). Participantes do encontro: Ilka Boaventura Leite (UFSC), Neusa Gusmão (Unesp), Lúcia Andrade (CPI-SP), Dimas Salustiano da Silva (advogado SMDDH-MA), João Batista Borges Pereira (USP) membro do Grupo de Trabalho da ABA que circunstancialmente não pôde estar presente, Eliane Cantarino O'Dwyer (tesoureira da $\mathrm{ABA}$ ) e João $\mathrm{Pa}$ checo de Oliveira (presidente da ABA).

90. A criação da Fundação Cultural Palmares se dá em 1988 , por meio da Lei $\mathrm{n}^{\circ}$ 7.668 , que no seu artigo $1^{\circ}$ afirma que o Poder Executivo está "autorizado a constituir a Fundação Cultural Palmares - FCP, vinculada ao Ministério da Cultura, com sede e foro no distrito Federal, com a finalidade de promover a preservação dos valores culturais, sociais e econômicos decorrentes da influência negra na formação da sociedade brasileira". Já o artigo $2^{\circ}$ afirma que cabe à Fundação: "I - promover e apoiar eventos relacionados com os seus objetivos, inclusive visando à interação cultural, social, econômica e política do negro no contexto social do país; II - promover e apoiar o intercâmbio com outros países e com entidades internacionais através do Ministério das Relações Exteriores, para a realização de pesquisas, estudos e eventos relativos à história e à cultura dos povos negros" (Brasil, 1988a).

91. Diz o artigo $2^{\circ}$ do Decreto $n^{\circ} 4.887 / 2003$ : "Consideram-se remanescentes das comunidades dos quilombos, para os fins deste decreto, os grupos étnico-raciais, segundo critérios de autoatribuição, com trajetória histórica própria 
dotados de relações territoriais específicas, com presunção de ancestralidade negra relacionada com a resistência à opressão histórica sofrida. $\S 1^{\circ}$ Para os fins deste Decreto, a caracterização dos remanescentes das comunidades dos quilombos será atestada mediante autodefinição da própria comunidade. $\S 2^{\circ}$ São terras ocupadas por remanescentes das comunidades dos quilombos as utilizadas para a garantia de sua reprodução física, social, econômica e cultural. $\S 3^{\circ}$ Para a medição e demarcação das terras, serão levados em consideração critérios de territorialidade indicados pelos remanescentes das comunidades dos quilombos, sendo facultado à comunidade interessada apresentar as peças técnicas para a instrução procedimental" (id., 2003).

92. Arruti, op. cit., p. 288.

93. Carvalho (2018) mostra as dificuldades das comunidades remanescentes de quilombos do Alto Trombetas II, no município de Oriximiná (PA), para a manutenção de seu modo de vida, sua cultura e das relações com o meio ambiente, que garantem a sobrevivência das comunidades por meio de atividades extrativistas. As comunidades tratadas pela autora participam do pedido de tombamento dos Quilombos de Oriximiná. Apesar das solicitações de arquivamento, o processo encontra-se em andamento até os dias atuais, mas sem definição. Ele não se refere a uma comunidade específica, mas à região de Oriximiná, da qual a comunidade Alto Trombetas II faz parte. Todas as comunidades quilombolas da região estão
Em relação às políticas federais de patrimônio, após 1988, onze pedidos de tombamento de quilombos foram abertos no Iphan com base no parágrafo $5^{\circ}$ do artigo 216 da CF/88. É importante registrar que várias dessas solicitações foram encaminhadas ao Iphan por meio da Fundação Cultural Palmares e do Ministério Público e procediam de comunidades que viviam em contexto de conflitos ligados à terra, como o pedido de tombamento dos Quilombos de Oriximiná, ${ }^{93}$ no Pará, com processo aberto em 7 de abril de 1995, e o pedido do Quilombo do Flexal, aberto no mesmo ano no município de Mirinzal, Maranhão - ambos em resposta à orientação do Ministério Público de $1992^{94}$ e encaminhados ao Iphan a partir de pareceres da Fundação Cultural Palmares. Como afirmado anteriormente, em um período de indefinição das atribuições institucionais e na ausência da regulamentação do artigo 68 do $A D C T$, o tombamento foi visto como alternativa na luta pela garantia de acesso à propriedade dos territórios ocupados..$^{95}$

Das solicitações feitas ao Iphan, apenas foi tombado, em 2002, o Quilombo do Ambrósio, em Minas Gerais, 96 a partir dos critérios tradicionais de valor histórico e arqueológico, pois ele foi considerado um caso de sítio arqueológico de valor excepcional. "Há aqui um elemento fundamental, por ser difícil fazer a classificação e submeter ao Iphan, para tombamento, reminiscentes ou remanescentes da história da escravidão negra em nosso país, porque são raras provas da cultura material tão abundantes como neste quilombo". 97 No período anterior ao Decreto n’ 3.551/2000, que instituiu o Registro de Bens de Natureza Imaterial como patrimônio cultural brasileiro, trabalhos ${ }^{98}$ mostram como o entendimento do Iphan acerca dos quilombos se ateve à ideia de vestígios arqueológicos ou manifestações puramente objetivas de cultura.

O Decreto n 3.551/2000, que instituiu o Registro de Bens Culturais de Natureza Imaterial e o Programa Nacional de Patrimônio Imaterial (PNPI), veio reconhecer que o campo cultural diz respeito à totalidade da vida social e que a ideia de continuidade do patrimônio imaterial se relaciona com a reiteração e recriação constantes das manifestações culturais pelos grupos e comunidades.

São as lutas de representação em torno da legitimidade do patrimônio e dos sujeitos de atribuição de valor, processadas ao longo daquelas duas décadas, que vão conferir sentido e encorpar os significados da noção de referência cultural, até que se torne uma categoria operacional, na metodologia do Inventário Nacional de Referências Culturais - INRC, elaborada em 2000.99 
A realização de Inventários Nacionais de Referências Culturais (INRCs) em comunidades quilombolas de alguns estados trabalhou com sua autoidentificação, que se articulava com a própria noção de referência cultural, considerada estruturante da política de patrimônio imaterial. Desse modo, é possível pensar na possibilidade de diferentes segmentos sociais se apropriarem de sua herança cultural e reivindicarem a valorização e o reconhecimento de qualquer tipo de patrimônio como um direito à memória.

A eleição dos novos bens, ou melhor, de novas formas de se conceber a condição de patrimônio cultural nacional, também permite que diferentes grupos sociais, utilizando as leis do Estado e o apoio de especialistas, revejam as imagens e alegorias do passado, do que querem guardar e definir como próprio e identitário. $\bigcirc$ decreto abre a possibilidade para o surgimento de novos canais de expressão cultural e luta política para grupos da sociedade civil antes silenciados, que são detentores de práticas culturais imateriais locais e tidas como tradicionais. ${ }^{100}$

referido Decreto $n^{\circ} 4.887 / 2003$ introduziu os grupos quilombolas no rol de populações atendidas por políticas diferenciadas. ${ }^{101}$ Assim, com a ampliação dos instrumentos utilizados para a identificação e o reconhecimento de patrimônios culturais pelo Estado, é importante perceber os usos de pedidos de registro e de inventários a partir de demandas por acesso a outras políticas governamentais, pois cada grupo recorre a esses instrumentos segundo as memórias locais e os contextos de conflitos em que se insere. Os diversos INRCs realizados em comunidades de remanescentes de quilombos têm a potencialidade de evidenciar o caráter dinâmico, relacional e contemporâneo desses grupos.

O registro do Sistema Agrícola Tradicional das Comunidades Quilombolas do Vale do Ribeira (SATQ Vale do Ribeira), 102 único bem com a designação "quilombola" no seu título, ocorreu na 90 Reunião do Conselho Consultivo do Patrimônio Cultural, no Rio de Janeiro, em 20 de setembro de 2018. Na análise de alguns documentos relativos a essa solicitação, recorrentemente há a afirmação de que o pedido de registro faz parte de uma estratégia de ação em defesa dos territórios ocupados pelas comunidades quilombolas e de seus modos de vida tradicionais, ${ }^{103}$ ou seja, o registro é pensado articuladamente com demandas por reparação.

Trata-se da segunda solicitação de registro de Sistema Agrícola Tradicional (SAT) recebida pelo Iphan, tendo sido precedida pela solicitação do SAT do Rio Negro, aprovada em 2010. Segundo o parecer da relatora do Conselho Consultivo do Patrimônio Cultural, a antropóloga Manoela Carneiro da Cunha, a ênfase nos processos envolvidos e não nos produtos, tal como propõe a política atualmente certificadas pela Fundação Cultural Palmares, mas há problemas na titulação definitiva dos territórios quilombolas. Muitos dos territórios ainda não titulados na região estão sobrepostos a unidades de conservação: a Reserva Biológica do Rio Trombetas, a Floresta Nacional Saracá-Taquera e a Floresta Estadual Trombetas. A autora afirma que, na região do Alto Trombetas II, o início da organização para o reconhecimento dos grupos ocorreu quase simultaneamente com a implantação de projetos minerários e de uma Unidade de Conservação no ano de 1979.

94. Ofício $\mathrm{n}^{\circ} 109$, de 21 de fevereiro de 1992, que encaminha cópia dos processos n ${ }^{\circ} 08100.003746 / 91-14$, $\mathrm{n}^{\circ} 08100.003746 / 91-59$ e $^{\circ}$ 08100.003746/91-99 e seus anexos, que tratam da existência da Comunidade Negra Rural de Frexal, no Maranhão, e dos Quilombos de Oriximiná, no Pará, para análise, parecer e encaminhamento ao Instituto Brasileiro do Patrimônio Cultural com vistas ao tombamento (Instituto do Patrimônio Histórico e Artístico Nacional, 1995a, f. 2; 1995b, f. 1).

95. Carvalho, op. cit.

96. Instituto do Patrimônio Histórico e Artístico Nacional (1998). Livro Histórico em 11 de julho de 2002.

97. Fala da conselheira Suzanna Sampaio (Ata da $25^{\mathrm{a}}$ reunião do Conselho Consultivo do Patrimônio Cultural, 2000, p. 13).

98. Cheibub (2015); Vaz (2016).

99. Chuva (2017, p. 91).

100. Abreu (2017, p. 356). 
101. Em 2004 foram criados o Programa Brasil Quilombola (PBQ)e a Agenda Social Quilombola, que objetivavam, de forma coordenada, agrupar rubricas de diferentes políticas pré-existentes. "Tais objetivos estavam voltados para a promoção de abordagens e mudanças de posturas internas às próprias comunidades atendidas: a promoção da agroecologia, de uma política de gênero e o estímulo ao protagonismo dos quilombolas em todos os processos de decisão, como forma de fortalecer sua identidade cultural e política. Os outros quatro objetivos do PBQ tinham a ver com mudanças de posturas e de abordagens internas ao próprio Estado nos diferentes níveis do poder executivo, tendo em vista o reconhecimento e o fortalecimento organizacional das comunidades de quilombos. Para isso, entravam em foco a própria elaboração e gestão das políticas públicas: $\mathrm{o}$ incentivo aos governos estaduais e municipais na promoção do acesso de quilombolas às políticas públicas, com ênfase na regularização da posse da terra e no estímulo ao desenvolvimento sustentável em seus territórios; a proposição de um modelo de gestão destas políticas que preserve a igualdade de oportunidade dada a estas comunidades, em comparação com os demais públicos; a garantia dos direitos sociais e do acesso à rede de proteção social, com a exigência de uma articulação entre os diferentes órgãos governamentais com ações nas mais diferentes áreas" (Arruti, op. cit., p. 288-289).

102. O SATQ Vale do Ribeira está situado no estado de São Paulo, nos municípios de Iguape (Comunidade do patrimônio imaterial, afirma a importância do reconhecimento do lphan na luta por territórios e modos de vida.

Uma das inovações então introduzidas foi a de colocar em realce não os produtos, por mais importantes que fossem - no caso do rio Negro, a extraordinária agrobiodiversidade observada - mas o próprio processo que conduzia a eles. Esse processo repousa em múltiplas dimensões solidárias entre si. Valores, conhecimentos de toda a sorte sobre a floresta e o clima, calendários e técnicas agrícolas e culinárias, cultura material, direito costumeiro, formas de sociabilidade, formas de transmissão de saberes, religiosidade, festejos, são algumas dessas dimensões, justificando o uso do termo "sistema", e configurando o que, na venerável antropologia de Mauss e Durkheim, se convencionou chamar de "fato social total". Abriu-se, portanto, caminho para o protagonismo do Iphan no reconhecimento dos ricos complexos culturais ligados às atividades agrícolas de povos indígenas e comunidades tradicionais brasileiras, em seus diversos biomas, dando visibilidade a esses importantes sistemas socioecológicos que vêm sendo ameaçados por problemas fundiários, pela imposição do modelo agrícola pós-Revolução Verde, e pela integração crescente dessas populações ao mercado. ${ }^{104}$

O registro solicitado pelas Associações Quilombolas do Vale do Ribeira em parceria com a organização não governamental Instituto Socioambiental (ISA) foi consequência da realização do Inventário Cultural das Comunidades Quilombolas do Vale do Ribeira, que ocorreu de 2009 a 2012 e foi fruto de um acordo de cooperação técnica entre ISA e Iphan, com a participação de pesquisadores quilombolas. ${ }^{105} \mathrm{Com} 180$ bens culturais identificados e tendo o sistema agrícola como eixo estruturante do modo de vida das comunidades quilombolas, o inventário também promoveu a capacitação de agentes culturais locais. Seu resultado foi publicado em 2013 , com o apoio do Iphan. ${ }^{106}$

O INRC e o registro aparecem junto a outras ações organizadas pelas comunidades quilombolas e parceiros desde meados da década de 2000, mostrando intensa organização dos grupos considerados para fazer suas reivindicações:

- Elaboração da Agenda Socioambiental das Comunidades Quilombolas do Vale do Ribeira, de 2007, que apresenta um retrato da situação e um plano de futuro das comunidades quilombolas, identificando pontos de atenção e as principais ações e políticas públicas a serem desenvolvidas, dentre elas, ações de incentivo agrícola e manutenção de valores e práticas culturais tradicionais.

- Formação do GT da Roça (em 2007), espaço permanente em que os quilombolas se reúnem para discutir entraves e fortalecer as práticas agrícolas nos territórios; espaço de organização da feira de sementes. 
- Realização anual, desde 2008, de uma Feira de Trocas de Mudas e Sementes Quilombolas para estimular o manejo da agrobiodiversidade e dar visibilidade ao patrimônio cultural e biológico associado para a sociedade em geral. [...]

- Criação da Cooperquivale, em 2012, visando articular e estimular a comercialização dos produtores quilombolas da região e facilitar o escoamento dos produtos e promover a geração de renda.

- A criação do Paiol de Sementes Quilombolas em 2015 com objetivo de fortalecer as trocas e a diversidade das sementes tradicionais quilombolas. ${ }^{107}$

Os documentos mostram que desde 1989, por conta da iminente construção da usina hidrelétrica de Tijuco Alto, no Rio Ribeira, os quilombolas contribuíram para fundar o Movimento dos Ameaçados por Barragem (Moab). Além dos empreendimentos desenvolvimentistas na região, ligados a mineração, madeira e monocultura, o estado de São Paulo criou Unidades de Conservação (UCs) sobrepostas aos territórios quilombolas, gerando restrições às roças tradicionais sob o argumento de que prejudicavam o meio ambiente. Desde a criação das UCs, antes de fazer a roça as comunidades precisam solicitar autorizações do Estado para a supressão florestal, gerando perdas dos ciclos de plantio e de variedades alimentares.

Nesse sentido, o INRC é apontado como instrumento que contribuiu para consolidar a "consciência da importância e riqueza do patrimônio cultural quilombola dentro das comunidades" 108 (dimensão cultural do reconhecimento). A identificação do "modo de fazer roça" como um bem cultural central e estruturante do modo de vida quilombola tem lastro na história da comunidade na região, além de desempenhar seu papel no presente para a segurança alimentar e a renda das famílias quilombolas do Vale do Ribeira.

Ademais, os argumentos para o registro designam o SATQ como "um conjunto rico e inter-relacionado de práticas e conhecimentos agrícolas, ecológicos, sociais, religiosos e lúdicos que resultam da experiência histórica dos negros na América e são transmitidos por gerações no território". 109 Nesse sentido, a construção da categoria SATQ e toda a pesquisa do INRC e do registro vêm qualificar a importância histórica dos afrodescendentes na formação social e cultural brasileira.
Morro Seco), Cananeia (Comunidade Mandira), Jacupiranga (Comunidade Poça), Eldorado (comunidades de Pedro Cubas, Pedro Cubas de Cima, Sapatu, André Lopes, Ivaporunduva, Galvão, Abobral e São Pedro), Iporanga (comunidades Piririca, Nhunguara, Porto Velho, Bombas, Pilões, Maria Rosa e Praia Grande) e Itaóca, (Comunidade Cangume), que pertencem à região conhecida como Vale do Ribeira (Andrade et al., 2019, p. 55).

103. Parecer técnico $n^{\circ}$ 9/2018/Coreg/CGIR/DPI (2018, p. 2) apud Instituto do Patrimônio Histórico e Artístico Nacional (2014).

104. Instituto do Patrimônio Histórico e Artístico Nacional (2014, p.4-5).

105. Noções como as de consentimento prévio e informado e participação social são importantes no desenvolvimento das ações governamentais ligadas aos bens patrimoniais.

106. Parecer técnico $\mathrm{n}^{\circ}$ 9/2018/Coreg/CGIR/DPI (2018, p. 2) apud Instituto do Patrimônio Histórico e Artístico Nacional (2014).

107. Andrade et al., op. cit., p. 73-74.

108. Ibid., p. 74 .

109. Ibid., p. 75.
O SATQ é possivelmente a expressão mais íntegra do modo de vida criado pelas comunidades negras do Vale do Ribeira desde o período colonial; representa ao mesmo tempo condição de existência e resultado da trajetória dos negros nessa região. Essa expressão é íntegra não só porque permanece viva, mas por ser uma instituição que coloca em relação aspectos fundamentais do tecido social: o parentesco, a linguagem, a reciprocidade, a economia, as relações com o meio, a religiosidade, o lazer e, mais recentemen- 
110. Ibid., p. 76-77.

111. Fraser, op. cit.

112. Parecer técnico $\mathrm{n}^{\circ}$ 9/2018/Coreg/CGIR/DPI (2018, p. 6) apud Instituto do Patrimônio Histórico e Artístico Nacional (2014).

113. Arruti, op. cit., p. 289290.

114. Honneth, op. cit. te, a política. [...] $\bigcirc$ Sistema Agrícola Tradicional Quilombola é expressão viva de um capítulo de pouca visibilidade da historiografia nacional, mas que, apesar disso, contém parte significativa da memória e identidade brasileiras. ${ }^{110}$

reconhecimento do SATQ demonstra as interconexões entre os direitos culturais, territoriais e ambientais para a salvaguarda dos modos de vida quilombolas, bem como a necessidade de políticas intersetoriais, diálogos e acordos interinstitucionais para a real possibilidade de preservação desse patrimônio. Para tanto, nos termos de Fraser, é preciso o atendimento de demandas de reconhecimento e de redistribuição. ${ }^{11}$

conhecimento gerado durante os processos de identificação e reconhecimento é o que permite diagnosticar, de modo bastante preciso, as formas mais adequadas de salvaguarda. A mobilização social de comunidades, grupos ou indivíduos vinculados à produção e reprodução do bem cultural é condição fundamental para o reconhecimento de suas identidades coletivas e, ainda, para transformar seus saberes práticos num vigoroso instrumento jurídico-formal. $\bigcirc$ dossiê entregue ao lphan demonstra que a utilização itinerante da floresta no território quilombola é um modelo de uso sustentável da Mata Atlântica, construindo assim representações positivas dos saberes e das práticas quilombolas, propiciando valorização, respeito e reconhecimento social:

[...] a importância dos conhecimentos dos quilombolas do Vale do Ribeira não se limita a uma área geográfica, mas diz respeito à preservação de um bioma por meio de um modelo eficiente de uso sustentável, que vem assegurando a conservação da Mata Atlântica na região já reconhecida como Patrimônio Natural da Humanidade pela Unesco. ${ }^{112}$

As políticas de patrimônio contribuíram e contribuem para a produção de conhecimentos, tal como o debate público sobre a escravidão auxilia na compreensão histórica da sociedade brasileira. As políticas culturais, como construtoras da necessidade de representação (estética, política etc.), devem merecer atenção redobrada pelo papel que podem ter na afetação de outras políticas.

Como foi possível demonstrar, em relação a comunidades quilombolas, as políticas patrimoniais, para além de reconhecerem o desrespeito histórico da escravidão e a posição subalterna dos afrodescendentes na sociedade brasileira, também reconhecem formas de organização social e cultural específicas que, nesse caso, geram a designação particular de "quilombola". ${ }^{113}$

Oreconhecimento e a valorização de certas manifestações culturais como quilombolas devem se refletir nas três esferas de reconhecimento de que fala Honneth. ${ }^{114}$ Desse modo, os processos e as ações de reparação sobre "comunidades remanescentes de quilombo" não podem perder de vista as diversas dimensões do reconhecimento social. 


\section{REFERÊNCIAS}

FONTES IMPRESSAS

ASSOCIAÇÃO BRASILEIRA DE ANTROPOLOGIA. Documento do Grupo de Trabalho sobre comunidades negras rurais no encontro realizado em 17/18 outubro de 1994 - ABA/Rio de Janeiro. Brasília, DF: ABA, 1994.

BOLETIM SPHAN/PRÓ-MEMÓRIA. Brasília, DF: Fundação Nacional Pró-Memória, n. 12, 1981a.

BOLETIM SPHAN/PRÓ-MEMÓRIA. Brasília, DF: Fundação Nacional Pró-Memória, n. 15, $1981 b$.

INSTITUTO DO PATRIMÔNIO HISTÓRICO E ARTÍSTICO NACIONAL. Processo de Tombamento $n^{\circ}$ 1.069-T-82: Serra da Barriga, Quilombo dos Palmares. Arquivo Noronha Santos. Rio de Janeiro: Iphan, 1982.

INSTITUTO DO PATRIMÔNIO HISTÓRICO E ARTÍSTICO NACIONAL. Processo de Tombamento $n^{\circ}$ 1.352-T-95: Quilombo de Frechal/Frexal/Flexal. Arquivo Noronha Santos. Rio de Janeiro: Iphan, 1995a.

INSTITUTO DO PATRIMÔNIO HISTÓRICO E ARTÍSTICO NACIONAL. Processo de Tombamento $n^{\circ}$ 1.353-T-95: Quilombos de Oriximiná. Arquivo Noronha Santos. Rio de Janeiro: Iphan, $1995 \mathrm{~b}$.

INSTITUTO DO PATRIMÔNIO HISTÓRICO E ARTÍSTICO NACIONAL. Processo de Tombamento $n^{\circ}$ 1.428-T-98: Quilombo de Ambrósio. Arquivo Noronha Santos. Rio de Janeiro: Iphan, 1998.

INSTITUTO DO PATRIMÔNIO HISTÓRICO E ARTÍSTICO NACIONAL. Ata da $117^{a}$ reunião do Conselbo Consultivo do Patrimônio Cultural. Brasília, DF: Iphan, 1985.

INSTITUTO DO PATRIMÔNIO HISTÓRICO E ARTÍSTICO NACIONAL. Ata da $25^{a}$ reunião do Conselbo Consultivo do Patrimônio Cultural, Brasília, DF: Iphan, 2000.

INSTITUTO DO PATRIMÔNIO HISTÓRICO E ARTÍSTICO NACIONAL. Processo Iphan $n^{\circ}$ 01450.004794/2014-59: solicitação de registro do Sistema Agrícola Tradicional Quilombola do Vale do Ribeira, SP. Brasília, DF: Iphan, 2014. 
LIVROS, ARTIGOS E TESES

ABREU, Marta. Cultura imaterial e patrimônio histórico nacional. In: Cultura Política e leituras do passado: historiografia e ensino de história. Rio de Janeiro: Civilização Brasileira, 2007.

ALMEIDA, Alfredo Wagner Berno de. Terra de quilombo, terras indigenas, "babaçuais livre”, "castanhais do povo", faixinais e fundos de pasto: terras tradicionalmente ocupadas. Manaus: Ufam, 2008.

ANDERSON, Benedict. Comunidades imaginadas: reflexões sobre a origem e a difusão do nacionalismo. São Paulo: Companhia das Letras, 2008.

ANDRADE, Anna Maria et al. Sistema Agrícola Tradicional Quilombola do Vale do Ribeira, SP. In: EIDT, Jane Simoni; UDRY, Consolacion (eds.). Sistemas Agrícolas Tradicionais do Brasil. Brasília, DF: Embrapa, 2019. p. 55-92.

ARANTES, Antônio Augusto. Introdução: cultura e cidadania. Revista do Patrimônio Histórico e Artístico Nacional, Brasília, DF, n. 24, p. 9-13, 1996.

ARRUTI, José Maurício. Diferenciar, redistribuir, reconhecer: ensaio de atualização dos debates sobre terra e educação para quilombos. Cadernos de Campo, São Paulo, n. 20, p. 285-294, 2011.

BRASIL. Lei $\mathrm{n}^{\circ}$ 7.668, de 22 de agosto de 1988. Autoriza o Poder Executivo a constituir a Fundação Cultural Palmares - FCP e dá outras providências. Diário Oficial da União, Brasília, DF, p. 160025, 23 ago. 1988a. Disponível em: <https://bit.ly/3oDIIt7>. Acesso em: 6 nov. 2020.

BRASIL. [Constituição (1988)]. Constituição da República Federativa do Brasil de 1988. Diário Oficial da União, Brasília, DF, 5 out. 1988b. Disponível em: <https://bit.ly/3oDIIt7>. Acesso em: 6 nov. 2020.

BRASIL. Decreto $\mathrm{n}^{\circ} 4.887$, de 20 de novembro de 2003. Regulamenta o procedimento para identificação, reconhecimento, delimitação, demarcação e titulação das terras ocupadas por remanescentes das comunidades dos quilombos de que trata o art. 68 do Ato das Disposições Constitucionais Transitórias. Diário Oficial da União, Brasília, DF, p. 4, 21 nov. 2003.

BRESSIANI, Nathalie. Redistribuição e reconhecimento: Nancy Fraser entre Jürgen Habermas e Axel Honneth. Caderno CRH, Salvador, v. 24, n. 62, p. 331-352, 2011.

CAMPOS, Yussef Daibert Salomão de. Desafios propostos pela Constituição de 1988 ao patrimônio cultural. Revista do Patrimônio Histórico e Artístico Nacional, Brasília, DF, n. 35, p. 203-211, 2017. 
CAMPOS, Yussef Daibert Salomão de. Os conceitos de lugar e território na composição do patrimônio cultural: quilombos e terras indígenas na Constituição Federal brasileira. Tempo $e$ Argumento, Florianópolis, v. 10, n. 25, p. 99-114, 2018.

CARVALHO, Luciana Gonçalves de. Aporias da proteção do patrimônio cultural e natural de uma comunidade de remanescente de quilombo na Amazônia. Revista do Patrimônio Histórico e Artístico Nacional, Brasília, DF, n. 37, p. 211-231, 2018.

CHEIBUB, Michelle de Carvalho. Patrimônio cultural e comunidades remanescentes de quilombos: direitos culturais e instrumentos de proteção do Iphan. 2015. Dissertação (Mestrado Profissional em Preservação do Patrimônio Cultural) - Instituto do Patrimônio Histórico e Artístico Nacional, Brasília, DF, 2015.

CHUVA, Márcia. Fundando a nação: a representação de um Brasil barroco, moderno e civilizado. Topoi, Rio de Janeiro, v. 4, n. 7, p. 313-333, 2003.

CHUVA, Márcia. Possíveis narrativas sobre duas décadas de patrimônio: de 1982 a 2002. Revista do Patrimônio Histórico e Artístico Nacional, Brasília, DF, n. 35, p. 79-103, 2017.

CICALO, André. Uma voz para o passado: a construção de patrimônio da escravidão na região portuária do Rio de Janeiro. In: MATTOS, Hebe (org.). História oral e comunidades: reparações e culturas negras. São Paulo: Letra e Voz, 2016. p. 49-70.

DOMINGUES, Petrônio; GOMES, Flávio. Histórias dos quilombos e memórias dos quilombolas no Brasil: revisitando um diálogo ausente na Lei 10.639/03. Revista da ABPN, Goiânia, v. 5, n. 11 , p. 5-28, 2013.

FONSECA, Maria Cecília Londres. Da modernização à participação: a política federal de preservação nos anos 70 e 80. Revista do Patrimônio Histórico e Artístico Nacional, Brasília, DF, n. 24, p. 153-164, 1996.

FONSECA, Maria Cecília Londres. O patrimônio em processo: trajetória da política federal de preservação no Brasil. Rio de Janeiro: Editora UFRJ, 2005.

FRASER, Nancy. Da redistribuição ao reconhecimento? Dilemas da justiça numa era "pós-socialista". Tradução de Júlio Assis Simões. Cadernos de Campo, São Paulo, n. 14/15, p. 231-239, 2006.

GONÇALVES, José Reginaldo. A retórica da perda: os discursos do patrimônio cultural no Brasil. Rio de Janeiro: Editora UFRJ, 1996.

GUIMARÃES, Antonio Sérgio Alfredo. Democracia racial: o ideal, o pacto e o mito. Novos Estudos Cebrap, São Paulo, n. 61, p. 147-162, 2001. 
HEYMANN, Luciana; ARRUTI, José Mauricio. Memória e reconhecimento: notas sobre as disputas contemporâneas pela gestão da memória na França e no Brasil. In: GONÇALVES, Márcia de Almeida et al. (orgs.). Qual o valor da história hoje? Rio de Janeiro: FGV, 2012. p. 96-119.

HOBSBAWM, Eric; RANGER, Terence. A invenção das tradições. 2. ed. São Paulo: Paz e Terra, 2012.

HONNETH, Axel. Luta por reconbecimento: a gramática moral dos conflitos sociais. Tradução de Luiz Repa. São Paulo: Editora 34, 2003.

LIMA, Antonio Carlos de Souza; CASTRO, João Paulo Macedo. Notas para uma abordagem antropológica da(s) política(s) pública(s). Revista Anthropológicas, Recife, v. 26, n. 2, p. 17-54, 2015.

MATTOS, Hebe. Introdução. In: MATTOS, Hebe (org.). História oral e comunidades: reparações e culturas negras. São Paulo: Letra e Voz, 2016. p. 7-14..

MENESES, Ulpiano Toledo Bezerra de. O campo do patrimônio cultural: uma revisão de premissas. In: INSTITUTO DO PATRIMÔNIO HISTÓRICO E ARTÍSTICO NACIONAL. I Fórum Nacional do Patrimônio Cultural: Sistema Nacional de Patrimônio Cultural: desafios, estratégias e experiências para uma nova gestão, Ouro Preto/MG, 2009. Brasília, DF: Iphan, 2012. v. 1, p. 25-39.

NOGUEIRA, Antonio Gilberto Ramos. Diversidade e sentidos do patrimônio cultural: uma proposta de leitura da trajetória de reconhecimento da cultura afro-brasileira como patrimônio nacional. Anos 90, Porto Alegre, v. 15, n. 27, p. 233-255, 2008.

REZENDE, Maria Beatriz; GRIECO, Bettina; TEIXEIRA, Luciano; THOMPSON, Analucia. Secretaria e Subsecretaria do Patrimônio Histórico e Artístico Nacional: 1979-1990. In: REZENDE, Maria Beatriz; GRIECO, Bettina; TEIXEIRA, Luciano; THOMPSON, Analucia (orgs.). Dicionário Iphan de patrimônio cultural. Rio de Janeiro: Copedoc/Iphan, 2015. Verbete. Disponível em: <https://bit.ly/354SAEl>. Acesso em: 6 nov. 2020.

SAILLANT, Francine. Reconhecimento e reparações: o exemplo do movimento negro no Brasil. In: MATTOS, Hebe (org.). História oral e comunidades: reparações e culturas negras. São Paulo: Letra e Voz, 2016. p. 17-48.

SERRA, Ordep José Trindade. Monumentos negros: uma experiência. Afro-Ásia, Salvador, n. 33, p. 169-205, 2005.

THOMPSON, Analucia. Campo cultural e contexto histórico: nomes do Iphan. In: Motta, Lia (org.). Um panorama do campo da preservação do patrimônio cultural. Rio de Janeiro: Copedoc/Iphan, 2015. p. 9-78. (Caderno de Estudos do PEP/MP, 9). 
VAZ, Beatriz Accioly. Quilombos. In: GRIECO, Bettina; TEIXEIRA, Luciano; THOMPSON, Analucia (orgs.). Dicionário Iphan de patrimônio cultural. 2. ed. rev. ampl. Rio de Janeiro: Copedoc/Iphan, 2016. Verbete. Disponível em: <https://bit.ly/3p2HbwX>. Acesso em: 6 nov. 2020.

VELHO, Gilberto. Antropologia e patrimônio cultural. Revista do Patrimônio Histórico e Artístico Nacional, Rio de Janeiro, n. 20, p. 37-39, 1984.

VELHO, Gilberto. Patrimônio, negociação e conflito. Mana [online]. vol.12, n.1. p.237-248, 2006.

SITES

ABDIAS Nascimento. In: ENCICLOPÉDIA Itaú Cultural de arte e cultura brasileiras. São Paulo: Itaú Cultural, 2018. Verbete. Disponível em: <https://bit.ly/31568oV>. Acesso em: 15 jul. 2020.

FREIRE, Jacqueline. Núcleo de Estudos Afro-Brasileiros comemora 33 anos durante Caiite 2015. Universidade Federal de Alagoas, Maceió, 12 jun. 2015. Disponível em: <https://bit. ly/2IfW2D5>. Acesso em: 16 jan. 2020.

JOEL Rufino dos Santos. Global Editora, São Paulo, 29 set. 2018. Disponível em: <https://bit. ly/354kmks>. Acesso em: 20 dez. 2019.

O QUE SÃO ações afirmativas? Gemaa, Rio de Janeiro, 24 ago. 2011. Disponível em: <https:// bit.ly/38q4066>. Acesso em: 10 jan. 2020.

Artigo apresentado em: 21/1/2020. Aprovado em 30/7/2020.

\section{(cc) BY}

